Biogeosciences, 10, 6793-6806, 2013

www.biogeosciences.net/10/6793/2013/

doi:10.5194/bg-10-6793-2013

(c) Author(s) 2013. CC Attribution 3.0 License.

\title{
Photooxidation of dimethylsulfide (DMS) in the Canadian Arctic
}

\author{
A. Taalba ${ }^{1}$, H. Xie ${ }^{1}$, M. G. Scarratt ${ }^{2}$, S. Bélanger ${ }^{3}$, and M. Levasseur ${ }^{4}$ \\ ${ }^{1}$ Institut des sciences de la mer de Rimouski, Université du Québec à Rimouski, Rimouski, Québec, G5L 3A1, Canada \\ ${ }^{2}$ Maurice Lamontagne Institute, Fisheries and Oceans Canada, Mont-Joli, Québec, G5H 3Z4, Canada \\ ${ }^{3}$ Département de biologie, chimie et géographie, Université du Québec à Rimouski, Rimouski, Québec, G5L 3A10, Canada \\ ${ }^{4}$ Département de biologie (Québec-Océan), Université Laval, Québec, Québec, G1V 0A6, Canada
}

Correspondence to: H. Xie (huixiang_xie@uqar.qc.ca)

Received: 14 December 2012 - Published in Biogeosciences Discuss.: 6 February 2013

Revised: 6 September 2013 - Accepted: 30 September 2013 - Published: 1 November 2013

\begin{abstract}
Photolysis of dimethylsulfide (DMS), a secondary photochemical process mediated by chromophoric dissolved organic matter (CDOM), has previously been demonstrated to be an important loss term of DMS in the surface layer of warm seas and the Southern Ocean. The role of photolysis in regulating the DMS dynamics in northern polar seas remains, however, less clear. This study for the first time determined the apparent quantum yield (AQY) spectra of DMS photooxidation in Canadian Arctic seas covering Baffin Bay, the Mackenzie estuary and shelf, and the Canada Basin. The DMS AQY was fairly invariant at salinities $<25$ but rose rapidly with further increasing salinity in an exponential manner. Salinity can therefore be used as a quantitative indicator of the DMS AQY. The DMS AQY in the ultraviolet (UV) wavelengths was linearly and positively correlated with the spectral slope coefficient (275-295 nm) of the CDOM absorption spectrum, suggesting that marine CDOM photosensitizes the degradation of DMS more efficiently than does terrestrial CDOM or that coastal waters contain higher concentrations of substrates (most likely dissolved organic matter and redox metals) that compete for DMSoxidizing radical intermediates. High concentrations of nitrate $\left(\sim 12 \mu \mathrm{mol} \mathrm{L}^{-1}\right)$ in deep water samples boosted DMS photooxidation by $70-80 \%$, due likely to radical chemistry of nitrate photolysis. Coupled optical-photochemical modeling, based on the obtained DMS AQY spectra, shows that UV-A (320-400 nm) accounted for $60-75 \%$ of the DMS photolysis in the sunlit surface layer and that photochemistry degraded DMS on an $e$-folding time from 9 to $100 \mathrm{~d}$ (mean: $29 \mathrm{~d}$ ). The photooxidation term on average accounted for $21 \%$ of the DMS gross loss rate and was comparable to the atmospheric DMS ventilation rate estimated for the
\end{abstract}

same geographic regions. The methodology adopted here to study the relationship between CDOM quality/origin and DMS AQYs, if applicable to other ocean areas, may bring results of global significance for DMS cycling and might have implications for probing other CDOM-driven photochemical processes.

\section{Introduction}

Dimethylsulfide (DMS) is the most abundant volatile sulfur compound in seawater and its egress from the ocean accounts for $\sim 50 \%$ of the total biogenic sulfur flux to the atmosphere (Bates et al., 1992; Liss et al., 1997). Upon entering the troposphere from the sea, DMS is rapidly oxidized to sulfate aerosols, potentially contributing to the formation of cloud condensation nuclei (CCN) (Lana et al., 2012; Kulmala et al., 2013). CCN increase cloud droplet number and hence cloud albedo, thereby reducing solar radiation arriving at Earth's surface (Andreae and Crutzen, 1997). Marine DMS, along with other oceanic precursors (e.g., sea salts and organics) of atmospheric aerosols, may thus moderate climate warming (Charlson et al., 1987; Quinn and Bates, 2011). Moreover, the cycling of marine DMS and its precursor, dimethylsulfoniopropionate (DMSP), implicates a cascade of processes that impact not only the sulfur and carbon biogeochemistry but also the ecology and physiology of marine phytoplankton and bacteria (Kiene et al., 2000; Simó, 2004).

In contrast to the enormous progress made in mapping the concentrations and air-sea fluxes of DMS in major ocean basins (e.g., Kettle et al., 1999; Lana et al., 2011; Yang et al., 2011), our knowledge of DMS distributions and fluxes

Published by Copernicus Publications on behalf of the European Geosciences Union. 
in Arctic seas remains rudimentary. Surface water DMS concentrations obtained from a limited number of Arctic field surveys are within ranges occurring in warmer oceans (Leck and Persson, 1996; Bouillon et al., 2002; Galí and Simó, 2010; Luce et al., 2011; Motard-Côté et al., 2012). Sharma et al. (1999) estimated that the efflux of DMS from the Arctic Ocean accounts for only $0.4 \%$ of the world ocean's total flux but could have a significant effect on the regional cloud albedo. More recent works on Arctic DMS fluxes arrived at similar conclusions (Chang et al., 2011; Rempillo et al., 2011). Moreover, rising seawater temperatures and increasing open water areas (Comiso, 2006) in the Arctic Ocean are expected to promote primary production (hence DMS formation) and accelerate air-sea exchange. Model simulations predicted that the Arctic DMS emission rate will increase by $90 \%$ if the atmospheric $\mathrm{CO}_{2}$ level triples and totally ice-free conditions materialize in summer (Gabric et al., 2005).

The amount of seawater DMS available for transfer to the atmosphere is controlled by in situ production and loss processes in the surface ocean. DMS is generated biologically by phytoplankton and bacteria (Yoch, 2002; Stefels et al., 2007); it is lost by bacterial uptake (Kiene and Bates, 1990; Simó, 2004), photolysis (Brimblecombe and Shooter, 1986), and ventilation to the atmosphere. DMS photolysis is a secondary photochemical process induced by oxidants produced primarily from photoreactions of chromophoric dissolved organic matter (CDOM) (Brimblecombe and Shooter, 1986; Toole et al., 2003). Compared to concentration distributions and air-sea fluxes, even less is known of the production and consumption rates of DMS in the Arctic, particularly for the photooxidation term. Like other CDOM photochemical processes, previous studies on DMS photooxidation in the Northern Hemisphere were predominantly restricted to low and midlatitudes due partly to the logistic challenges of field surveys in the high north and partly to the implicit assumption that photochemistry is irrelevant in the Arctic where low solar angles and extensive ice cover minimize the solar radiation available for aquatic photoprocesses (Amon and Meon, 2004). However, ongoing global changes appear to favor photoreactions in Arctic environments. First, Arctic climate warming shrinks ice extent and shortens the ice cover period (Comiso, 2006), thereby allowing more solar energy to be passed into the water column. Second, warming-induced melting of Arctic permafrost may increase the input of terrestrial CDOM to the Arctic Ocean (Retamal et al., 2008; Stedmon et al., 2011); CDOM is the primary substrate of marine photochemistry. Third, declining stratospheric ozone over the high northern latitudes leads to increasing ultraviolet (UV) radiation reaching the sea surface (Rex et al., 2004). Finally, strong surface water stratification in the Arctic Ocean, which could be further intensified by growing freshwater runoff and ice melting (Rabe et al., 2011), increases substrate exposure to solar radiation on a per-molecule basis. These factors combined together could synergistically enhance the photooxidation potential in the water column. Indeed, recent studies have observed significant photochemical CDOM transformation in the western Canadian Arctic under current ice conditions in terms of carbon monoxide (Xie et al., 2009), carbon dioxide (Bélanger et al., 2006) and ammonium photoproduction (Xie et al., 2012). Modeling studies point to strengthened photooxidation under a totally ice-free scenario in the summer season (Bélanger et al., 2006; Xie et al., 2012).

Galí and Simó (2010) determined DMS photooxidation rates in waters off Greenland and concluded that photolysis and biological consumption rates are comparable within the upper mixed layer during summer under shallow stratification conditions. Deal et al. (2005) measured the pseudo-firstorder apparent quantum yield (AQY) spectra of DMS photolysis in seawater from two Bering Sea stations. Their results indicate that the loss of DMS through photolysis is comparable to that by air-sea exchange in the Bering Sea in late summer. To our knowledge, these are to date the only published surveys of DMS photooxidation in the Arctic Ocean. Here we report the first measurement of the AQY spectra of DMS photolysis in Canadian Arctic marine environments covering the Mackenzie estuary and shelf, Canada Basin, and Baffin Bay. We modeled the photochemical DMS turnover rate constants based on the obtained AQY spectra and discussed the implication of photooxidation for DMS cycling in northern marine systems.

\section{Materials and methods}

\subsection{Sampling}

Sampling was conducted aboard the icebreaker CCGS Amundsen in the southeastern (SE) Beaufort Sea in late June and July 2008 and in the Baffin Bay/Lancaster Sound area in September 2008 as part of the field campaigns for the 2007-2008 IPY's (International Polar Year) CFL (Circumpolar Flaw Lead system study) and Canadian Arctic SOLAS (Surface Ocean-Lower Atmosphere Study) programs. The SE Beaufort Sea was re-visited in August 2009 during the Mackenzie Light and Carbon (Malina) program (Fig. 1). The SE Beaufort Sea survey covered the Mackenzie River estuary, Mackenzie Shelf, and Canada Basin. Zodiac rafts were deployed during the Malina cruise to collect shallow waters in the estuary that included two salinity-gradient transects: one in the east channel covering stations from 391 to 398 and the other in the west channel encompassing stations from 691 to 698. The eastern Canadian Arctic was sampled at three localities, Sta. 303 in the Lancaster Sound and Sta. 126 and 140 in the northeastern Baffin Bay (Fig. 1). Only surface water samples $(0-5 \mathrm{~m})$ were collected except for Sta. 1526 at which three depths down to $950 \mathrm{~m}$ were sampled. Samples from the salinity-gradient transects were taken with a clean high-density polyethylene (HDPE) bucket and transferred into $10 \mathrm{~L}$ acid-cleaned HDPE jugs. Elsewhere, $12 \mathrm{~L}$ Niskin 
Table 1. Sampling information and related physical and chemical properties. MRE-E: Mackenzie River estuary east channel; MRE-W: Mackenzie River estuary west channel; MS: Mackenzie Shelf; CB: Canada Basin; BB: Baffin Bay; n.d.: not determined; <DL: under the detection limit. Sampling depths of $0-0.2 \mathrm{~m}$ denote bucket samples. The separation of MRE-E and MRE-W from MS is only intended to facilitate discussion in the text. All MRE-E and MER-W stations were actually located on the MS.

\begin{tabular}{|c|c|c|c|c|c|c|c|c|c|c|c|}
\hline Region & Station & Cruise & $\begin{array}{c}\text { Date } \\
\text { dd-mm-yy }\end{array}$ & $\begin{array}{l}\text { Latitude } \\
\qquad\left({ }^{\circ} \mathrm{N}\right)\end{array}$ & $\begin{array}{l}\text { Longitude } \\
\qquad\left({ }^{\circ} \mathrm{W}\right)\end{array}$ & $\begin{array}{r}\text { Sampling } \\
\text { depth } \\
(\mathrm{m})\end{array}$ & $\begin{array}{r}\text { Bottom } \\
\text { depth } \\
(\mathrm{m})\end{array}$ & Salinity & $\begin{array}{r}T \\
\left({ }^{\circ} \mathrm{C}\right)\end{array}$ & $\begin{array}{r}a_{\text {cdom }, 412} \\
\quad\left(\mathrm{~m}^{-1}\right)\end{array}$ & $\begin{array}{l}\mathrm{NO}_{3}^{-} \\
(\mu \mathrm{M})\end{array}$ \\
\hline \multirow[t]{7}{*}{ MRE-E } & So & CFL & $30-06-08$ & 69.27 & 134.09 & $0-0.2$ & 1.0 & 0 & n.d. & 2.14 & 3.53 \\
\hline & 3 & CFL & 29-07-08 & 69.50 & 133.25 & $0-0.2$ & 3.8 & 11.1 & 14.9 & 1.56 & 0.51 \\
\hline & 391 & Malina & $16-08-09$ & 70.10 & 133.54 & $0-0.2$ & 34.6 & 27.82 & 3.2 & 0.13 & 0.01 \\
\hline & 394 & Malina & $16-08-09$ & 69.85 & 133.49 & $0-0.2$ & 12.4 & 21.46 & 8.8 & 0.82 & 0.01 \\
\hline & 396 & Malina & $16-08-09$ & 69.68 & 133.46 & $0-0.2$ & 6.3 & 17.27 & 8.2 & 1.11 & 0.12 \\
\hline & 398 & Malina & $16-08-09$ & 69.53 & 133.42 & $0-0.2$ & 3.1 & 16.37 & 8.8 & 1.23 & 0.70 \\
\hline & 434 & CFL & $30-06-08$ & 70.18 & 133.56 & 2.7 & 40.0 & 29.03 & 3.6 & 0.28 & 0.40 \\
\hline \multirow[t]{5}{*}{ MRE-W } & 691 & Malina & $13-08-09$ & 69.39 & 137.79 & $0-0.2$ & 43.7 & 23.61 & 5.2 & 0.39 & $<\mathrm{DL}$ \\
\hline & 693 & Malina & $13-08-09$ & 69.30 & 137.40 & $0-0.2$ & 32.3 & 15 & 8.8 & 1.15 & 0.63 \\
\hline & 694 & Malina & 13-08-09 & 69.25 & 137.20 & $0-0.2$ & 9.0 & 9.43 & 9.3 & 1.66 & 1.79 \\
\hline & 695 & Malina & 13-08-09 & 69.20 & 137.01 & $0-0.2$ & 5.0 & 7.04 & 9.3 & 1.89 & 2.60 \\
\hline & 697 & Malina & $13-08-09$ & 69.13 & 136.68 & $0-0.2$ & 1.7 & 0.15 & 10.3 & 2.04 & 3.62 \\
\hline \multirow[t]{2}{*}{ MS } & 170 & Malina & 07-08-09 & 70.92 & 128.92 & 3 & 35 & 29.01 & 3.2 & 0.20 & $<\mathrm{DL}$ \\
\hline & 670 & Malina & $10-08-09$ & 69.80 & 138.43 & 3 & 174 & 23.5 & 4 & 0.33 & 0.01 \\
\hline \multirow[t]{5}{*}{$\mathrm{CB}$} & 320 & Malina & 09-08-09 & 71.56 & 133.96 & 2.8 & 1159 & 26.46 & -0.8 & 0.10 & 0.01 \\
\hline & 640 & Malina & 11-08-09 & 70.33 & 139.10 & 3.3 & 564 & 21.43 & 2.1 & 0.24 & n.d. \\
\hline & 1526 & CFL & 03-07-08 & 72.01 & 131.33 & 5 & 1050 & 25.47 & -0.9 & 0.17 & 0.30 \\
\hline & 1526 & CFL & 03-07-08 & 72.01 & 131.33 & 160 & 1050 & 33.66 & -1.5 & 0.11 & 12.1 \\
\hline & 1526 & CFL & 03-07-08 & 72.01 & 131.33 & 950 & 1050 & 34.87 & 0 & 0.09 & 12.2 \\
\hline \multirow[t]{3}{*}{$\mathrm{BB}$} & 126 & SOLAS & $18-09-08$ & 77.35 & 73.42 & $0-0.2$ & 326 & 31.59 & 3.1 & 0.05 & 0.29 \\
\hline & 140 & SOLAS & 11-09-08 & 75.04 & 64.49 & $0-0.2$ & 280 & 30.88 & 3.6 & 0.06 & 0.05 \\
\hline & 303 & SOLAS & 07-09-08 & 74.23 & 89.65 & $0-0.2$ & 228 & 30.98 & 0.3 & 0.10 & 0.14 \\
\hline
\end{tabular}

bottles mounted on a rosette sampler were employed. Salinity and water temperature were recorded using a SeaBird 911+ CTD (conductivity, temperature, depth) profiler. All samples were gravity-filtered upon collection through a Pall AcroPak 1000 filtration capsule sequentially containing 0.8 and $0.2 \mu \mathrm{m}$ polyethersulfone membranes, which had been thoroughly rinsed with Nanopure and sample water. Filtered water was transferred to acid-cleaned $4 \mathrm{~L}$ clear glass bottles and stored at $4{ }^{\circ} \mathrm{C}$ in darkness until further treatment in a land-based laboratory in Rimouski, Québec. Detailed sampling information can be found in Table 1 .

\subsection{Irradiation}

Prior to irradiation, water samples were re-filtered through $0.2 \mu \mathrm{m}$ polyethersulfone membranes (PALL) and amended with an aqueous DMS stock solution to yield a final concentration of $\sim 10 \mathrm{nmol} \mathrm{L}^{-1}$. Samples were then siphoned into pre-combusted quartz-windowed cells (inner diameter: $3.4 \mathrm{~cm}$; length: $11.4 \mathrm{~cm}$ ) with clean Teflon tubing. The cell was overflowed by twice its volume before being closed without headspace. The irradiation procedure followed that reported by Zhang et al. (2006) for determining carbon monoxide photoproduction. Briefly, samples in the quartz cells were irradiated in a temperature-controlled water bath $\left(2-4{ }^{\circ} \mathrm{C}\right)$ under polychromatic radiation emitted from a SUNSET CPS solar simulator equipped with a $1.5 \mathrm{~kW}$ xenon lamp. To retrieve DMS AQY spectra (see Sect. 2.4), eight light treatments were applied by screening the incident light through eight successive Schott long-band glass cutoff filters with model numbers of WG280, WG295, WG305, WG320, WG345, GG395, GG435 and GG495. The numeric values in the model numbers signify the nominal $50 \%$ transmittance cutoff wavelengths. Spectral irradiance under each cutoff filter was measured at $1 \mathrm{~nm}$ increments from 250 to $700 \mathrm{~nm}$ using an Optronics OL-754 spectroradiometer outfitted with a fiber optic cable having a terminal Teflon diffuser and calibrated with an OL752-10E irradiance standard. Light exposure spanned $2.5 \mathrm{~h}$ for samples under shortwave cutoff filters (WG280, WG295, WG305, and WG320) and $4 \mathrm{~h}$ under longwave cutoff filters (WG345, GG395, GG435 and GG495). For each experiment, parallel dark controls were incubated to account for any thermal loss of DMS. 


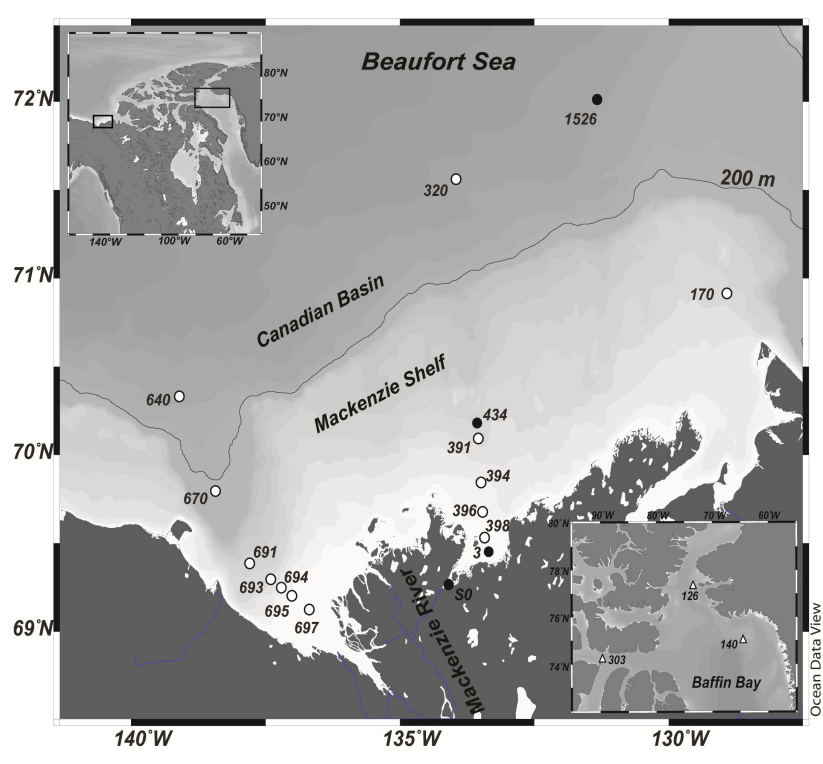

Fig. 1. Sampling map showing the Beaufort Sea (Mackenzie Shelf and Canadian Basin) in the western Canadian Arctic and Baffin Bay in the eastern Canadian Arctic. Filled circles denote CFL stations in June and July 2008, open circles signify Malina stations in August 2009, and open triangles represent SOLAS stations in September 2008.

\subsection{Analysis}

DMS in pre- and post-irradiation samples was concentrated with a purge-and-trap device and then quantified using a gas chromatograph (GC) (Varian 3400 or 3800) fitted with a pulsed flame photometric detector (GC-PFPD) (Scarratt et al., 2000). Briefly, samples were bubbled for $3 \mathrm{~min}$ with gaseous helium $\left(60 \mathrm{~mL} \mathrm{~min}^{-1}\right)$ in a heated purging vessel (ca. $\left.70^{\circ} \mathrm{C}\right)$. The upper part of the vessel $(15 \mathrm{~cm}$ long) was kept at $5{ }^{\circ} \mathrm{C}$ to reduce water vapor in the gas stream without condensation of DMS. A Pyrex drying tube containing calcium chloride removed residual water vapor in the gas stream exiting the purging vessel before a Teflon loop submerged in liquid nitrogen cryotrapped the DMS. The Teflon loop was then heated to $\sim 70^{\circ} \mathrm{C}$, releasing the trapped volatiles onto the GC column. The system was calibrated using a certified permeation tube source (Kin-Tek Laboratories) delivering DMS at $500 \mathrm{ng} \mathrm{min}^{-1}$. The helium-diluted DMS stream from the permeation tube was passed through the purging apparatus and subjected to subsequent processing in the same manner as the samples. The quantification limit was $0.03 \mathrm{nmol} \mathrm{L}^{-1}$ based on 3 times the background noise. The precision of the method was better than $10 \%$ (coefficient of variation).

CDOM absorbance in pre- and post-irradiation samples was measured at room temperature from 250 to $800 \mathrm{~nm}$ at $1 \mathrm{~nm}$ increments using a Perkin-Elmer Lambda 35 dual beam UV-visible spectrometer referenced to Nanopure water and equipped with a $10 \mathrm{~cm}$ quartz cuvette. For highly colored samples in the inner part of the Mackenzie estuary, a $5 \mathrm{~cm}$ quartz cuvette was used to ensure that the measured absorbances fell within the upper limit of the Lambert-Beer law (i.e., $\sim 1$ ). The average absorbance over the $683-687 \mathrm{~nm}$ interval was subtracted as a background correction from the rest of the spectrum (Babin et al., 2003). Absorbance at wavelength $\lambda(\mathrm{nm}), A_{\mathrm{cdom}, \lambda}$, was converted to absorption coefficient (base $e), a_{\mathrm{cdom}, \lambda}\left(\mathrm{m}^{-1}\right)$, according to Eq. (1):

$a_{\text {cdom }, \lambda}=2.303 A_{\text {cdom }, \lambda} r^{-1}$,

where $r$ is the path-length of the quartz cuvette (m). The lower detection limit of $a_{\text {cdom }}$, defined as 3 times the standard deviation of five replicate analyses of pure water, was $0.02 \pm 0.01 \mathrm{~m}^{-1}$ across the $250-700 \mathrm{~nm}$ range.

Concentrations of nitrate in original samples, stored frozen at $-80^{\circ} \mathrm{C}$, were determined using a Technicon III (Bran+Luebbe) Autoanalyzer with colorimetric methods adapted from Grasshoff et al. (1999).

\subsection{Retrieval of AQY of DMS photooxidation}

The spectral AQY of DMS photolysis, $\Phi_{\mathrm{dms}, \lambda}$, is defined as the moles of DMS degraded per mole of photons absorbed by CDOM at wavelength $\lambda$. As a secondary photochemical reaction, DMS photolysis obeys pseudo-first-order kinetics (Brimblecombe and Shooter, 1986). Following the practice of Bouillon and Miller (2004) and Bouillon et al. (2006), we define a pseudo-first-order AQY of DMS photolysis, $\Phi_{\mathrm{dms}, \lambda}^{*}$ $\left[\mathrm{m}^{3} \text { (mol photons) }\right)^{-1}$ ], which is $\Phi_{\mathrm{dms}, \lambda}$ divided by DMS concentration ([DMS], moles $\mathrm{m}^{-3}$ ). $\Phi_{\mathrm{dms}, \lambda}^{*}$ is derived according to the protocol reported by Bouillon and Miller (2004) and Bouillon et al. (2006). Briefly, the rate of DMS photolysis in an irradiation cell can be expressed by Eq. (2):

$$
\begin{gathered}
-\frac{\mathrm{d}[\mathrm{DMS}]}{\mathrm{d} t}=[\mathrm{DMS}] R^{-1} \int_{280}^{500} Q_{0, \lambda} \\
{\left[1-\exp \left(-a_{\mathrm{cdom}+\mathrm{w}, \lambda} R\right)\right] \Phi_{\mathrm{dms}, \lambda}^{*} \mathrm{~d} \lambda}
\end{gathered}
$$

where $R$ is the path length of the irradiation cell, $Q_{0, \lambda}$ the incident spectral photon flux (mol photons $\mathrm{m}^{-2} \mathrm{~s}^{-1} \mathrm{~nm}^{-1}$ ), and $a_{\mathrm{cdom}+\mathrm{w}, \lambda}$ the sum of the absorption coefficients of CDOM and water $\left(a_{\mathrm{w}, \lambda}\right)$ (Pope and Fry, 1997; Buiteveld et al., 1994). Integrating the left-hand side of Eq. (2) from time zero $\left([\mathrm{DMS}]_{0}\right)$ to $t\left([\mathrm{DMS}]_{\mathrm{t}}\right)$ arrives at Eq. (3):

$$
\begin{gathered}
\ln \left(\frac{[\mathrm{DMS}]_{0}}{[\mathrm{DMS}]_{\mathrm{t}}}\right) t^{-1}=R^{-1} \int_{280}^{500} Q_{0, \lambda}\left[1-\exp \left(-a_{\mathrm{cdom}+\mathrm{w}, \lambda} R\right)\right] \\
\Phi_{\mathrm{dms}, \lambda}^{*} \mathrm{~d} \lambda
\end{gathered}
$$

All terms in Eq. (3) are known except $\Phi_{\mathrm{dms}, \lambda}^{*}$, allowing $\Phi_{\mathrm{dms}, \lambda}^{*}$ to be derived using a statistical optimization approach 
originally proposed by Rundel (1983) and adapted later by Xie et al. (1998) and Johannessen and Miller (2001). This approach assumes an exponential decay of $\Phi_{\mathrm{dms}, \lambda}^{*}$ :

$\Phi_{\mathrm{dms}, \lambda}^{*}=\Phi_{\mathrm{dms}, \lambda_{\mathrm{ref}}}^{*} \exp \left[-S_{\Phi_{\mathrm{dms}}^{*}}\left(\lambda-\lambda_{\text {ref }}\right)\right]$.

$\Phi_{\mathrm{dms}, \lambda_{\mathrm{ref}}}^{*}$ is $\Phi_{\mathrm{dms}, \lambda}^{*}$ at the reference wavelength $(290 \mathrm{~nm})$ and $S_{\Phi_{\mathrm{dms}}^{*}}$ denotes the spectral slope coefficient representing the spectral shape of $\Phi_{\mathrm{dms}, \lambda}^{*}$. The pseudo-first-order DMS photolysis rate in an irradiation cell can then be predicted from Eq. (4) using the assumed function of $\Phi_{\mathrm{dms}, \lambda}^{*}$ with initial estimates of $\Phi_{\mathrm{dms}, \lambda_{\mathrm{ref}}}^{*}$ and $S_{\Phi_{\mathrm{dms}}^{*}}$. The optimum $\Phi_{\mathrm{dms}, \lambda_{\text {ref }}}^{*}$ and $S_{\Phi_{\mathrm{dms}}^{*}}$ values were identified with a MATLAB-coded, iterative fit method by varying $\Phi_{\mathrm{dms}}^{*} \lambda_{\text {ref }}$ and $S_{\Phi_{\mathrm{dms}}^{*}}$ until the minimum residuals reached between the measured and predicted pseudo-first-order DMS photolysis rates for all samples from a single irradiation. The predicted rates agreed well with the measured ones with $R^{2}$ ranging from 0.943 to 0.996 (mean: $0.989, n=22$, Table 2).

\subsection{Modeling photochemical turnover of DMS}

The photochemical decay of [DMS] in the upper mixed layer, which was generally deeper than the photoactive layer (see Sect. 3.3), can be expressed by

$$
\begin{aligned}
& {[\mathrm{DMS}]_{\mathrm{col}, t}=[\mathrm{DMS}]_{\mathrm{col}, 0}} \\
& \quad \exp \left[-\left(Z_{\mathrm{ml}}^{-1} \int_{290}^{500} Q_{\mathrm{d}, 0-, \lambda} \frac{a_{\mathrm{cdom}, \lambda}}{a_{\mathrm{t}, \lambda}} \Phi_{\mathrm{dms}, \lambda}^{*} \mathrm{~d} \lambda\right) t\right] .
\end{aligned}
$$

$[\mathrm{DMS}]_{\mathrm{col}, 0}$ and $[\mathrm{DMS}]_{\mathrm{col}, t}$ are the depth-integrated DMS concentrations (i.e., column burden, $\mu \mathrm{mol} \mathrm{m}^{-2}$ ) at time zero and $t(\mathrm{~d})$, respectively. $Z_{\mathrm{ml}}$ denotes the upper mixedlayer depth (UMLD, $\mathrm{m}$ ), which was calculated using the $0.05 \mathrm{~kg} \mathrm{~m}^{-3}$ density difference criterion (Table 3 ), $Q_{\mathrm{d}, 0-, \lambda}$ is the downwelling solar photon flux just below the sea surface (mol photons $\mathrm{m}^{-2} \mathrm{~d}^{-1} \mathrm{~nm}^{-1}$ ), and $a_{\mathrm{t}, \lambda}$ is the total absorption coefficient $\left(\mathrm{m}^{-1}\right)$, i.e., $a_{\mathrm{t}, \lambda}=a_{\mathrm{cdom}, \lambda}+a_{\mathrm{p}, \lambda}+a_{\mathrm{w}, \lambda}$, where $a_{\mathrm{p}, \lambda}$ is the absorption coefficient of total particulate matter. $Q_{\mathrm{d}, 0-, \lambda}$ was derived from model simulations at $3 \mathrm{~h}$ intervals using the Santa Barbara DISORT Atmospheric Radiative Transfer (SBDART) software (Ricchiazzi et al., 1998), accounting for the cloud cover and ozone conditions. Values of simulation parameters such as cloud fraction, cloud optical thickness, and ozone abundance were obtained from the International Satellite Cloud Climatology Project website (http://isccp.giss.nasa.gov/products/browsed2.html). Readers are referred to the study by Song et al. (2013) for the methodology of particle absorption measurement and for the Malina $a_{\mathrm{p}, \lambda}$ data. The term within the parentheses in Eq. (5) is the photolysis rate constant, $k_{\mathrm{dms}}\left(\mathrm{d}^{-1}\right)$, i.e.,

$k_{\mathrm{dms}}=Z_{\mathrm{ml}}^{-1} \int_{290}^{500} Q_{\mathrm{d}, 0-, \lambda} \frac{a_{\mathrm{cdom}, \lambda}}{a_{\mathrm{t}, \lambda}} \Phi_{\mathrm{dms}, \lambda}^{*} \mathrm{~d} \lambda$.
Note that Eq. (6) neglects backscattering of solar radiation to the atmosphere and assumes vertical homogeneity of [DMS], $\Phi_{\mathrm{dms}}^{*}$ and absorption coefficients of various optical constituents in the upper mixed layer. The daily averaged $Q_{\mathrm{d}, 0-, \lambda}$ value on each station's sampling date was used to calculate $k_{\mathrm{dms}}$.

\section{Results and discussion}

\subsection{General physical and chemical properties}

The 2008 CFL survey in the SE Beaufort Sea covered the most extensive ranges of salinity (0-34.87) and water temperature $\left(-1.5\right.$ to $\left.14.9^{\circ} \mathrm{C}\right)$ and represented the overall ranges of the entire data sets of the two parameters (Table 1). The temperature and salinity profiles of Sta. 1562 (not shown) indicate that the $5 \mathrm{~m}$ sample was within the upper polar mixed layer characterized by relatively low salinities caused by ice melting and runoff, the $160 \mathrm{~m}$ sample was located in the upper halocline formed by Pacific winter water, and the $950 \mathrm{~m}$ sample originated from the North Atlantic (Matsuoka et al., 2012). The 2009 Malina cruise in the SE Beaufort Sea encountered surface water temperatures ranging from -0.8 (Sta. 320) to $10.3^{\circ} \mathrm{C}$ (Sta. 697) and salinity spanning from 0.15 (Sta. 697) to 27.82 (Sta. 391) (Table 1). Evidently, water temperature during both CFL and Malina declined from the Mackenzie River estuary to the Mackenzie Shelf to the Canada Basin and salinity climbed from the estuary to the shelf. However, Sta. 320, 640 and 1526 in the basin exhibited lower salinities than did certain stations on the shelf (e.g., Sta. 320 vs. Sta. 391; Sta. 640 vs. Sta. 670 and 691; Sta. 1526 vs. Sta. 434), probably due to a stronger presence of ice meltwater in the basin in summer (Xie et al., 2012). The three stations visited during SOLAS in the eastern Canadian Arctic displayed little variation in surface water temperature $\left(0.3-3.6^{\circ} \mathrm{C}\right)$ and salinity (30.88-31.59). These thermohaline properties reflected the influence of the Pacific water flowing from the western Canadian Arctic to Baffin Bay through the Canadian Archipelago (Melling et al., 2001).

The CDOM absorption coefficient along the Malina's two salinity-gradient transects showed linear anti-correlations with salinity (Fig. 2); CDOM in the Mackenzie estuary was thus mainly controlled by conservative mixing. Station 697 was an exception having $a_{\mathrm{cdom}, 412}$ of $20 \%$ lower than extrapolated from the $a_{\mathrm{cdom}, 412}$-salinity regression line for the west salinity-gradient transect, implying CDOM input near the head of the west channel of the estuary. CDOM in the east channel was consistently higher than in the west channel, suggesting either a higher riverine CDOM end member in the east channel or a larger CDOM addition at the start of estuarine mixing in the east. The zero salinity sample from CFL (Sta. S0) was only slightly higher in $a_{\mathrm{cdom}, 412}$ than the near-zero sample from Malina (Sta. 697) in spite of different sampling season (late June 2008 vs. mid-August 2009) and 
Table 2. Fitted $\Phi_{\mathrm{dms}, \lambda_{\text {ref }}}^{*}$ and $S_{\Phi_{\mathrm{dms}}^{*}}$ values for Eq. (4) in the text. Also shown are irradiation temperature and $\Phi_{\mathrm{dms}, 330}^{*}$ calculated from Eq. (4). $R^{2}$ is the coefficient of determination for regression of the predicted DMS photodegradation rate against the measured rate in an irradiation cell (see Sect. 2.4). Keys for the "Region" column are the same as in Table 1.

\begin{tabular}{|c|c|c|c|c|c|c|}
\hline Region & Station & $\begin{array}{l}\text { Irr. T } \\
\left({ }^{\circ} \mathrm{C}\right)\end{array}$ & $\begin{array}{c}\Phi_{\mathrm{dms}, \lambda_{\text {ref }}}^{*} \\
\left(\mathrm{~m}^{3}(\text { mole photons })^{-1}\right)\end{array}$ & $\begin{array}{c}S_{\Phi_{\mathrm{dms}}^{*}} \\
\left(\mathrm{~nm}^{-1}\right)\end{array}$ & $R^{2}$ & $\begin{array}{c}\Phi_{\mathrm{dms}, 330}^{*} \\
\left(\mathrm{~m}^{3}(\text { mole photons })^{-1}\right)\end{array}$ \\
\hline \multirow[t]{7}{*}{ MRE-E } & So & 2.0 & 0.30 & 0.037 & 0.987 & 0.07 \\
\hline & 3 & 2.0 & 0.58 & 0.039 & 0.995 & 0.12 \\
\hline & 391 & 4.0 & 0.66 & 0.020 & 0.982 & 0.30 \\
\hline & 394 & 4.0 & 0.37 & 0.030 & 0.974 & 0.11 \\
\hline & 396 & 4.0 & 0.18 & 0.021 & 0.989 & 0.08 \\
\hline & 398 & 4.0 & 0.16 & 0.022 & 0.970 & 0.07 \\
\hline & 434 & 2.0 & 1.19 & 0.044 & 0.992 & 0.20 \\
\hline \multirow[t]{5}{*}{ MER-W } & 691 & 4.0 & 0.36 & 0.025 & 0.943 & 0.14 \\
\hline & 693 & 4.0 & 0.18 & 0.014 & 0.971 & 0.11 \\
\hline & 694 & 4.0 & 0.37 & 0.038 & 0.980 & 0.08 \\
\hline & 695 & 4.0 & 0.10 & 0.011 & 0.981 & 0.06 \\
\hline & 697 & 4.0 & 0.26 & 0.034 & 0.994 & 0.07 \\
\hline \multirow[t]{2}{*}{ MS } & 170 & 4.0 & 0.96 & 0.039 & 0.995 & 0.20 \\
\hline & 670 & 4.0 & 0.51 & 0.019 & 0.985 & 0.24 \\
\hline \multirow[t]{5}{*}{$\mathrm{CB}$} & 320 & 4.0 & 1.27 & 0.034 & 0.952 & 0.33 \\
\hline & 640 & 4.0 & 0.94 & 0.032 & 0.990 & 0.26 \\
\hline & $1526(5 \mathrm{~m})$ & 2.0 & 2.42 & 0.063 & 0.996 & 0.19 \\
\hline & $1526(160 \mathrm{~m})$ & 2.0 & 6.10 & 0.051 & 0.984 & 0.81 \\
\hline & $1526(950 \mathrm{~m})$ & 2.0 & 18.0 & 0.061 & 0.992 & 1.54 \\
\hline \multirow[t]{3}{*}{$\mathrm{BB}$} & 303 & 2.0 & 1.57 & 0.024 & 0.967 & 0.60 \\
\hline & 140 & 2.0 & 0.79 & 0.010 & 0.994 & 0.53 \\
\hline & 126 & 2.0 & 2.15 & 0.022 & 0.993 & 0.91 \\
\hline
\end{tabular}

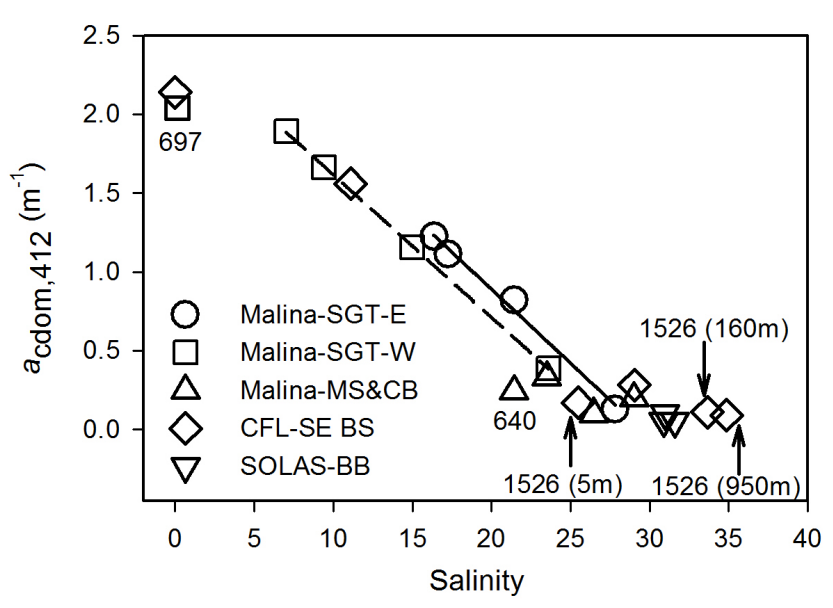

Fig. 2. Scatter plot of CDOM absorption coefficient at $412 \mathrm{~nm}$ versus salinity. SGT-E: salinity gradient transect east channel; SGTW: salinity gradient transect west channel; MS: Mackenzie Shelf; CB: Canada Basin; SE BS: southeastern Beaufort Sea, including the Mackenzie River estuary, Mackenzie Shelf, and Canada Basin; BB: Baffin Bay. location (east vs. west channel). The ice meltwater-diluted surface water at Sta. 640 and 1526 showed lower $a_{\text {cdom,412 }}$ than expected from salinity, congruent with a previous finding that meltwater is deprived of CDOM (Matsuoka et al., 2012). The subsurface samples at Sta. 1526, regardless of Pacific or Atlantic origin, were enriched with CDOM relative to their salinities. The CDOM absorption values of the three Baffin Bay stations conformed to the $a_{\text {cdom,412-salinity }}$ trend for the SE Beaufort Sea, which is in line with the eastward transport of the surface water in the western Canadian Arctic, as mentioned earlier.

\subsection{AQY and action spectra of DMS photooxidation}

Fitted parameters of Eq. (4) for deriving $\Phi_{\text {dms }}^{*}$ are shown in Table 2 and examples of $\Phi_{\mathrm{dms}}^{*}$ spectra are displayed in Fig. 3. $\Phi_{\mathrm{dms}}^{*}$ spectra representative of the Mackenzie River estuary (Sta. 697), the Mackenzie Shelf (Sta. 691), and the Canada Basin (Sta. 640) indicate that $\Phi_{\mathrm{dms}}^{*}$ increased from inshore to offshore with the difference climbing toward the short wavelengths (Fig. 3d). The surface action spectra were calculated as the products of $\Phi_{\text {dms }}^{*}, Q_{\text {surf, } \lambda}$ (Fig. 3a) and $a_{\text {cdom, }, \lambda}$ (Fig. 3b), where $Q_{\text {surf }, \lambda}$ (mol photons $\mathrm{m}^{-2} \mathrm{~s}^{-1} \mathrm{~nm}^{-1}$ ) denotes the surface spectral solar photon flux at $70^{\circ} \mathrm{N}, 133^{\circ} \mathrm{W}$ 
and 14:00 LT on 1 July, simulated using the SMARTS model (Gueymard, 2001) under mid-summer Arctic atmospheric and cloudless conditions with an ozone column burden of 330 Dobson units. The spectra show a non-Gaussian shape, peaking at $\sim 330 \mathrm{~nm}$ and slightly tailing into the visible (Fig. 3e). Despite $\Phi_{\mathrm{dms}}^{*}$ being higher at the offshore Sta. 640, its surface action spectrum was well below that for the inshore Sta. 697 due to the highly elevated CDOM abundance in the estuarine water (Fig. 3b). The depth-integrated action spectra were computed as products of $\Phi_{\mathrm{dms}}^{*}, Q_{\text {surf }, \lambda}$ and $a_{\mathrm{cdom}, \lambda} / a_{\mathrm{t}}$. Their shapes resembled those of the surface action spectra but were further shifted toward the visible because of the deeper penetration into the water column by visible wavelengths as compared with UV. Contrasting with the surface action spectra, the depth-integrated action spectra of Sta. 640 and 691 lay far above that of Sta. 697, where particles contributed a lot more to the total absorption than at the other two stations (Song et al., 2013), hence leading to a much lower $a_{\text {cdom }} / a_{\mathrm{t}}$ ratio (Fig. 3c). The relative contributions of UV-B (290-320 nm), UV-A (320-400 nm), and visible $(400-500 \mathrm{~nm})$ to the full-spectrum DMS photolysis were assessed by integrating the spectral curves in Fig. 3e and $\mathrm{f}$ over the relevant wavelength ranges. Estimates indicate that UV-B, UV-A, and visible, respectively, contributed $\sim 10-20$, $\sim 75$, and $\sim 4-15 \%$ at the surface and $\sim 5-15, \sim 60-75$, and $\sim 10-35 \%$ on a depth-integrated basis. UV-A thus dominated DMS photolysis both at the surface and in the entire water column, which is consistent with the results reported for warmer waters in the Pacific and Atlantic oceans (Kieber et al., 1996; Toole et al., 2003, 2004; Bouillon et al., 2006) and polar waters in the Bearing Sea (Deal et al., 2005).

Scatter plots of $\Phi_{\mathrm{dms}}^{*}$ against salinity, pooling data from all three cruises, indicate $\Phi_{\mathrm{dms}}^{*}$ in the UV regime remained rather constant below salinity 25 but increased rapidly above salinity 30 , which can be described by a 3-parameter exponential form having a constant intercept (Fig. 4a, b). It is interesting to note that data from other marine environments, including the Sargasso Sea, the NE Pacific, the Bering Sea, and the lower St. Lawrence estuary, also nicely fit this trend. This characteristic pattern, nevertheless, became obscure across the visible wavelengths (Fig. 4c). Note that the DMS AQYs for the Sargasso Sea, NE Pacific, and Bering Sea were all determined at $20-21^{\circ} \mathrm{C}$, which were $16-19^{\circ} \mathrm{C}$ higher than the irradiation temperatures employed in the present study. Correction for the temperature-dependence of DMS photolysis based on the result of Toole et al. (2003) for the Sargasso Sea somewhat decreases the coefficients of determination, but the correlation between $\Phi_{\mathrm{dms}}^{*}$ and salinity still remains highly significant $(p<0.0001)$ at the UV wavelengths (Fig. 4d, e). Salinity can thus be used potentially as a cross-system indicator of $\Phi_{\mathrm{dms}}^{*}$ within the UV spectral range, which, if confirmed in the future, lays a basis for modeling DMS photolysis rates on large spatial scales. Since $a_{\text {cdom }}$ was approximately anti-correlated with salinity (Fig. 2), the
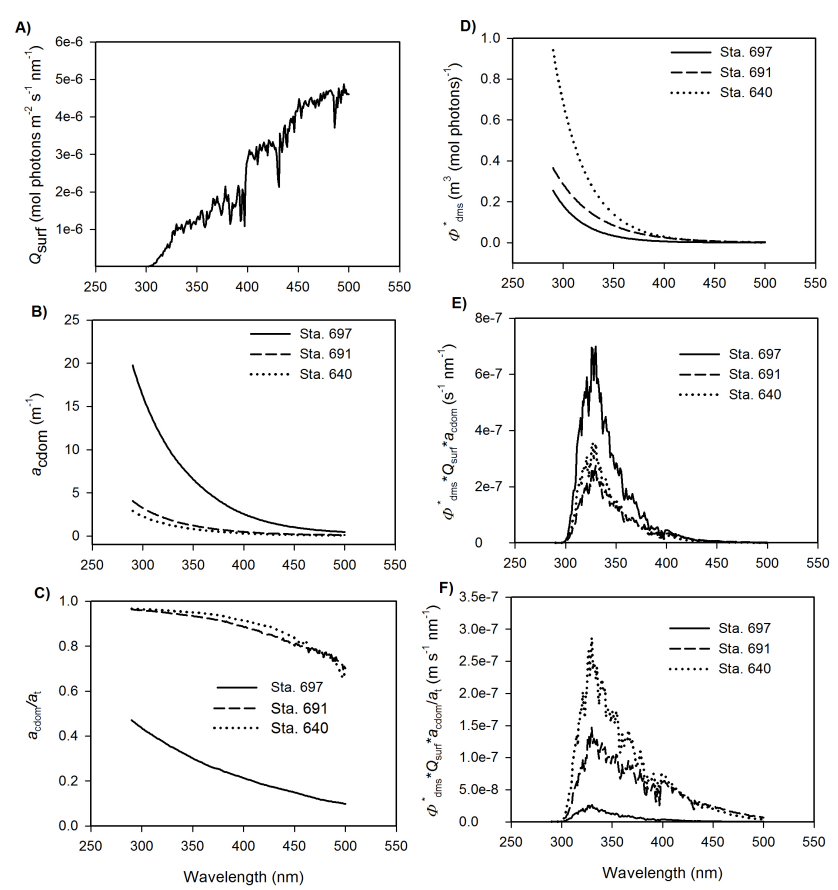

Fig. 3. Surface solar irradiance spectrum (a, see definition in Sect. 3.2), examples of CDOM absorption spectra (b) and their corresponding CDOM to total absorption ratios (c), DMS photolysis AQY spectra (d), and surface and water-column DMS photolyis action spectra $(\mathbf{e}, \mathbf{f})$.

$\Phi_{\mathrm{dms}}^{*}-a_{\mathrm{cdom}}$ relationship roughly mirrored that of $\Phi_{\mathrm{dms}}^{*}$ salinity but with relatively lower $R^{2}$ (data not shown).

Although increasing ionic strength (hence salinity) has been alluded to favor DMS photolysis (Yang et al., 2007), the dominant factor controlling this photoprocess in natural waters is thought to be CDOM, which indirectly oxidizes DMS via photoproduction of reactive oxygen species, such as singlet oxygen, hydroxyl radicals, and superoxide radicals (Brimblecombe and Shooter, 1986; Toole et al., 2004). As offshore waters are less impacted by terrestrial runoff in which CDOM is usually enriched with aromatic moieties relative to marine CDOM (Benner, 1998 and references therein), the striking difference in $\Phi_{\mathrm{dms}}^{*}$ between low- and high-salinity samples (Fig. 4) might result from differing photosensitizing capacities of terrestrial and marine CDOM with respect to DMS photooxidation. To further confirm this proposition, $\Phi_{\mathrm{dms}}^{*}$ is plotted against the spectral slope coefficient of CDOM over the wavelength range from 275 to $295 \mathrm{~nm}\left(S_{275-295}\right) . S_{275-295}$ has been proven to be a tracer of terrigenous dissolved organic matter with lower $S_{275-295}$ values indicating higher contents of land-derived materials (Fichot and Benner, 2012). Figure 5 manifests that $\Phi_{\mathrm{dms}}^{*}$ increased with rising $S_{275-295}$, linearly in the UV domain and exponentially across the visible span. Notwithstanding photobleaching can raise $S_{275-295}$ (Helms et al., 2008; Fichot and Benner, 2012), the generally conservative behavior 

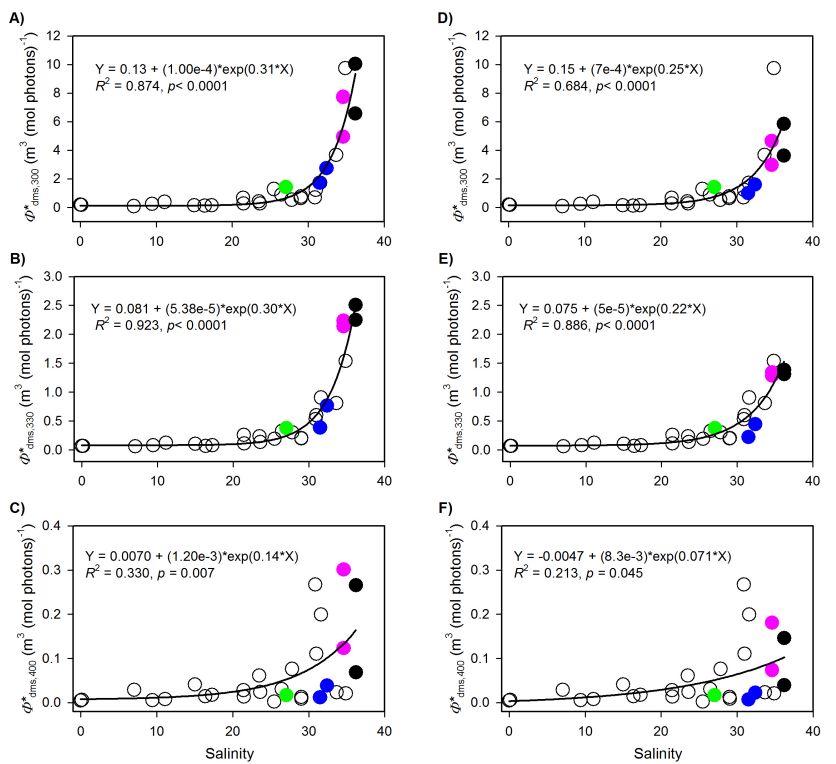

Fig. 4. Scatter plots of DMS photolysis AQY versus salinity for AQY at 300 (a, d), 330 (b, e), and $400 \mathrm{~nm}(\mathbf{c}, \mathbf{f})$. Open circles denote data from this study, filled blue circles from the Bering Sea (Deal et al., 2005), filled red circles from the NE subarctic Pacific (Bouillon and Miller 2004, their out-patch values), filled black circles from the Sargasso Sea (Toole et al., 2003). The solid green circles signify data obtained from a sample freshly collected from the lower St. Lawrence estuary off Mont-Joli, Québec $\left(48.5833^{\circ} \mathrm{N}\right.$, $68.1833^{\circ} \mathrm{W}$ ). DMS AQYs in panels (a-c) were not corrected for temperature dependence; in panels (d-f), DMS AQYs for the Sargasso Sea, NE Pacific, and Bering Sea were scaled to $4{ }^{\circ} \mathrm{C}$ (the irradiation temperature in the present study) based on the result of Toole et al. (2003). Solid lines are best fits to the data.

of CDOM (Sect. 3.1; also see Xie et al., 2012) suggests that photobleaching should not be an important factor controlling $S_{275-295}$ in the study area. Therefore, it appears that marine CDOM, which is rich in alkyl carbons (Benner, 1998), photosensitized the oxidation of DMS more efficiently than aromatic carbon-dominated terrigenous CDOM on an absorbed-photon basis. This is somewhat counterintuitive, since aromatic-rich CDOM is considered to be more photoreactive in general (Zepp, 2003). An alternative explanation is that there are more substrates in coastal waters competing for DMS-oxidizing radical intermediates. The most probable candidates of such substrates are dissolved organic matter and redox metals (e.g., $\mathrm{Fe}, \mathrm{Cu}, \mathrm{Mn}$ ), which are more abundant in coastal waters than in open oceans and which effectively react with radical intermediates such as hydroxyl radicals (e.g., Miller et al., 1995; Westerhoff et al., 2007). Further investigations are needed to elucidate the mechanisms behind the $\Phi_{\mathrm{dms}}^{*}$-salinity relationship observed in the present study. The quantitative relationship between $\Phi_{\mathrm{dms}}^{*}$ and $S_{275-295}$ identified here points to the possibility of using remote sensing to study DMS photolysis, since $S_{275-295}$
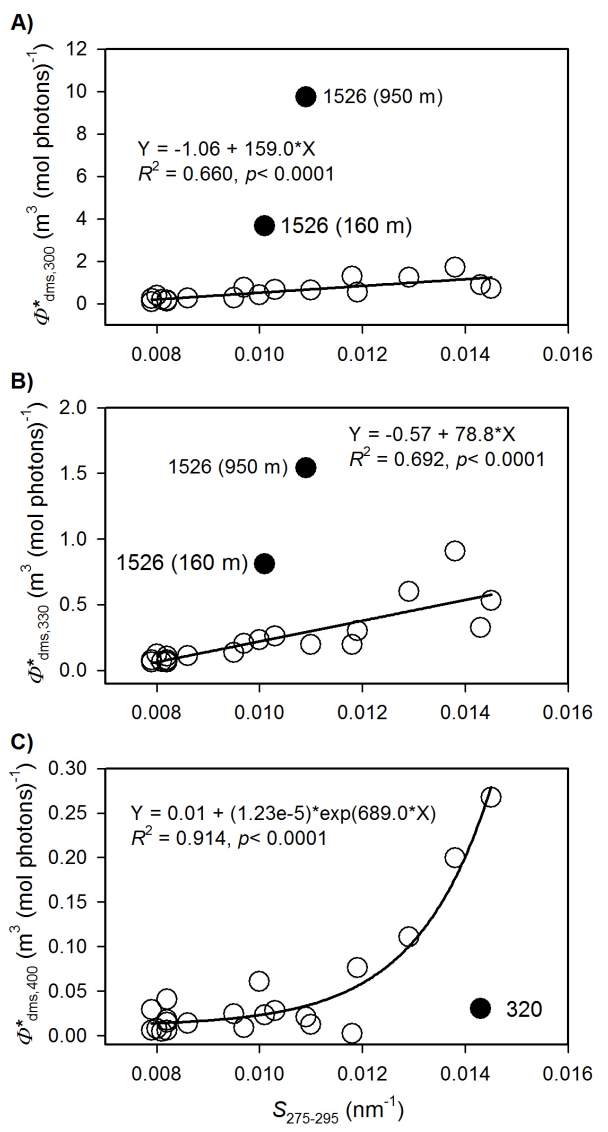

Fig. 5. Scatter plots of DMS photolysis AQY versus CDOM's spectral slope coefficient (275-295 nm) for AQY at 300 (a), 330 (b), and $400 \mathrm{~nm}$ (c). Solid lines are best fits to the data excluding outliers indicated by filled symbols with station numbers. Spectral slope coefficients were non-linearly computed from the model of $a_{\mathrm{cdom}, \lambda}=a_{\mathrm{cdom}, \lambda 0} \times \exp \left[S \times\left(\lambda_{0}-\lambda\right)\right]$, where $\lambda_{0}$ is a reference wavelength.

can be retrieved from satellite-based ocean color data (Fichot et al., 2013).

Note that the $\Phi_{\mathrm{dms}}^{*}$ values at the UV wavelengths for the deep samples (160 and $950 \mathrm{~m}$ ) in the Canada Basin (Sta. 1526) strayed far upward from the $\Phi_{\mathrm{dms}}^{*}-\mathrm{S}_{275-295}$ trend lines (Fig. 5a, b). These elevated $\Phi_{\mathrm{dms}}^{*}$ values are consistent with the much higher concentrations of nitrate observed at the deeper depths $\left(\sim 12 \mu \mathrm{mol} \mathrm{L}{ }^{-1}\right.$, Table 1$)$. Photolysis of nitrate has been identified as an alternative route for DMS photooxidation in nitrate-rich natural waters (Bouillon and Miller, 2004; Toole et al., 2004). The enhancement of DMS photooxidation in the presence of nitrate is ascribed to the production of DMS-oxidizing $\mathrm{HO}^{\bullet}$ (directly) and $\mathrm{Br}_{2}^{-\bullet}$ (indirectly) radicals from nitrate photolysis (Bouillon and Miller, 2005). The relationship between $\Phi_{\mathrm{dms}, 330}^{*}$ and nitrate concentration reported by Bouillon and Miller (2004) indicates that nitrate photolysis can account for $81 \%$ of the DMS photooxidation at a nitrate concentration of $12 \mu \mathrm{mol} \mathrm{L}^{-1}$. The 
$\Phi_{\mathrm{dms}, 330}^{*}$ values for the deep samples at Sta. 1526 are $72-$ $81 \%$ higher than those expected from the $\Phi_{\mathrm{dms}, 330}^{*}-S_{275-295}$ regression line (Fig. 5b), broadly agreeing with the prediction of Bouillon and Miller (2004). The absence of the nitrate enhancement effect in the visible (Fig. 5c) conforms to the fact that nitrate only absorbs short UV radiation (Mack and Bolton, 1999). The nitrate concentrations in surface samples having salinity $\geq 15$ were very low (undetectable to $0.7 \mu \mathrm{mol} \mathrm{L}{ }^{-1}$, Table 1 ), leading to negligible effects on DMS photolysis. The low-salinity (0-9.43) estuarine samples, though having moderate nitrate levels (1.79$3.62 \mu \mathrm{mol} \mathrm{L}^{-1}$, Table 1), showed no perceptible nitrate influence, either. This could be attributed to the low concentrations of the bromide anion in freshwater, since the bromide anion likely plays a key role in the nitrate-induced photooxidation of DMS, particularly in solutions of low dissolved inorganic carbon concentrations (Bouillon and Miller, 2005).

\subsection{Photochemical turnover of DMS}

The photochemical turnover rate constants $\left(k_{\mathrm{dms}}\right)$ in the surface mixed layer can be estimated from Eq. (6). Note that this equation requires that the depth of the photoactive layer, defined herein as the $1 \%$ penetration depth for the radiation at $330 \mathrm{~nm}\left(\mathrm{Z}_{1 \%, 330}, \mathrm{~m}\right)$, was shallower than the UMLD so that the most photochemically active radiation was absorbed within the upper mixed layer. We estimated $Z_{1} \%, 330$ from $a_{\mathrm{t}, 330}$, which is an underestimate of the diffusive attenuation coefficient at $330 \mathrm{~nm}$ due to the exclusion of the scattering coefficients of particles and water. The obtained $Z_{1 \%, 330}$ was always shallower than the UMLD except for three offshore stations $(126,320,391)$ at which the $\mathrm{Z}_{1 \%, 330}$ was slightly deeper than the UMLD (Table 3 ). The $k_{\mathrm{dms}}$ values estimated from Eq. (6) for each sampling station are displayed in Table 3, along with other relevant variables. Eq. (6) indicates that $k_{\mathrm{dms}}$ is positively related to $\Phi_{\mathrm{dms}}^{*}$, the $a_{\mathrm{cdom}} / a_{\mathrm{t}}$ ratio and solar irradiance but is inversely proportional to the surface mixed layer depth. Data of $k_{\mathrm{dms}}$ pooled from all three field surveys ranged from 0.01 to $0.11 \mathrm{~d}^{-1}$ and averaged $0.034 \mathrm{~d}^{-1}$ with a standard deviation of $0.022 \mathrm{~d}^{-1}$. The highest $k_{\mathrm{dms}}\left(0.11 \mathrm{~d}^{-1}\right)$ occurred at Sta. 391 with relatively large DMS AQYs $\left.\left(\Phi_{\mathrm{dms}, 330}^{*}: 0.30 \mathrm{~m}^{3} \text { (mol photons) }\right)^{-1}\right)$, moderately high $a_{\text {cdom }} / a_{\mathrm{t}}$ ratios $(0.87$ at $330 \mathrm{~nm})$, and a shallow mixed layer $(4.0 \mathrm{~m})$ while one of the two lowest rate constants $\left(0.01 \mathrm{~d}^{-1}\right)$ was observed at Sta. 170 having smaller AQYs $\left(\Phi_{\mathrm{dms}, 330}^{*}: 0.2 \mathrm{~m}^{3}\right.$ (mol photons) ${ }^{-1}$ ), lower $a_{\text {cdom }} / a_{\mathrm{t}}$ ratios $(0.66$ at $330 \mathrm{~nm})$, and a much deeper mixed layer $(11.5 \mathrm{~m})$. The other lowest $k_{\mathrm{dms}}$ appeared at Sta. 1526 , at which the positive effect of strong solar radiation $\left(Q_{\mathrm{d}, 0-}: 19.3 \mathrm{~mol}\right.$ photons $\left.\mathrm{m}^{-2} \mathrm{~d}^{-1}\right)$ and high $a_{\mathrm{cdom}} / a_{\mathrm{t}}$ ratios $(0.93$ at $330 \mathrm{~nm})$ was overtaken by the negative effect of deep mixing $(19.0 \mathrm{~m})$ and a sharply tilted AQY spectrum $\left(S_{\Phi_{\mathrm{dm}}^{*}}: 0.063 \mathrm{~nm}^{-1}\right)$. Per subdivision, the Mackenzie Shelf, including the two estuarine transects, on average exhibited the most elevated $k_{\mathrm{dms}}$ (mean \pm s.d.: $0.038 \pm 0.025 \mathrm{~d}^{-1}$ ) followed by the Baffin Bay $\left(0.027 \pm 0.004 \mathrm{~d}^{-1}\right)$ and the Canada Basin $\left(0.018 \pm 0.010 \mathrm{~d}^{-1}\right)$. Clearly, despite the lower AQYs $\left(\Phi_{\mathrm{dms}, 330}^{*}: 0.13 \pm 0.07 \mathrm{~m}^{3}(\mathrm{~mol}\right.$ photons $\left.)^{-1}\right)$ and $a_{\text {cdom }} / a_{\mathrm{t}}$ ratios $(0.76 \pm 0.19$ at $330 \mathrm{~nm})$ on the Mackenzie Shelf as compared to those in the Canada Basin $\left(\Phi_{\mathrm{dms}, 330}^{*}: 0.26 \pm 0.07 \mathrm{~m}^{3}\right.$ (mol photons) ${ }^{-1}$; $\left.a_{\mathrm{cdom}, 330} / a_{\mathrm{t}, 330}: 0.94 \pm 0.12\right)$ and Baffin Bay $\left(\Phi_{\mathrm{dms}, 330}^{*}\right.$ : $0.68 \pm 0.20 \mathrm{~m}^{3}$ (mol photons) ${ }^{-1} ; a_{\mathrm{cdom}, 330} / a_{\mathrm{t}, 330}: 0.93$ ), the far shallower mixed layer depth on the Mackenzie Shelf $(4.6 \pm 2.9 \mathrm{~m})$ led to $k_{\mathrm{dms}}$ surpassing those in the Canada Basin and Baffin Bay where the UMLD both averaged $\sim 14 \mathrm{~m}$.

The photochemical DMS turnover rate constants available in the literature vary by more than two orders of magnitude $\left(0.02-2.5 \mathrm{~d}^{-1}\right)$. The rate constants from the present study are within the lower bounds of those previously reported (Table 4). In comparison with other high-latitude seas, our values are close to those observed in the Bering Sea (0.02$0.11 \mathrm{~d}^{-1}$, Deal et al., 2005) and Ross Sea (0.037-0.17 $\mathrm{d}^{-1}$, Del Valle et al., 2009) but much lower than the ones found in the Greenland Sea (0.23-1.05 d $\mathrm{d}^{-1}$, Galí and Simó, 2010) and northern Ross Sea (0.5-0.71 d $\mathrm{d}^{-1}$, Toole et al., 2004). Many factors could cause such large discrepancies, the most prominent ones being solar irradiance, DMS AQY, UMLD, and water turbidity. For example, the waters surveyed by Toole et al. (2004) were highly enriched in nitrate $\left(28.5 \mu \mathrm{mol} \mathrm{L}^{-1}\right)$, giving rise to a $\Phi_{\mathrm{dms}, 330}^{*}$ of $4.7 \mathrm{~m}^{3}$ (mol photons ${ }^{-1}$ ) according to the $\Phi_{\mathrm{dms}, 330^{-}}^{*}$ nitrate relationship proposed by Bouillon and Miller (2004). This $\Phi_{\mathrm{dms}, 330}^{*}$ is 20 times the average $\Phi_{\mathrm{dms}, 330}^{*}$ of our surface water samples $\left(0.23 \pm 0.22 \mathrm{~m}^{3}\right.$ (mol photons $)^{-1}$ ), which alone could explain the majority of the variability between the two studies. Moreover, while previous studies mainly surveyed clear, open-ocean waters in which CDOM dominates the absorption of UV radiation, the present study sampled waters within the Mackenzie River plume containing sizable amounts of particles that accounted for up to $30-65 \%$ of the total light absorption at $330 \mathrm{~nm}$ (Table 3). The strong competition for light by particles led to lower $k_{\text {dms }}$ (Eq. 6).

Previous investigations have demonstrated that the photochemical route accounts for between 7 and $75 \%$ of the total DMS loss in the surface ocean (Kieber et al., 1996; Toole et al., 2003, 2004; Bouillon et al., 2006; Galí and Simó, 2010), thereby making an important contribution to the spatiotemporal variability of DMS concentrations in various oceanic environments. Under shallow stratification or nitrate-replete conditions, photolysis may even exceed bacterial uptake in DMS removal (Toole et al., 2004; Galí and Simó, 2010). There is currently a dearth of bacterial DMS consumption measurements in the Arctic Ocean. Limited data available indicate a large variability of bacterial DMS consumption turnover times in the upper mixed layer, ranging from $\sim 1 \mathrm{~d}$ in the Greenland Sea (Galí and Simó, 2010) to $\sim 3 \mathrm{~d}$ in the Barents Sea (Matrai and Vernet, 1997) to $\sim 13 \mathrm{~d}$ in the central 
Table 3. Photochemical DMS turnover rate constants $\left(k_{\mathrm{dms}}\right)$ and the corresponding $a_{\mathrm{cdom}, 330} / a_{\mathrm{t}, 330}$ ratios, upper mixed layer depths (UMLD), $1 \%$ penetration depths for radiation at $330 \mathrm{~nm}\left(\mathrm{Z}_{1} \%, 330\right)$, integrated photon fluxes of PAR (400-700 nm), UV (290-400 nm) and downwelling solar radiation (290-500 nm) just below the sea surface $\left(Q_{\mathrm{d}, 0-}\right)$. Absorption coefficients for CFL stations (Sta. S0, 3, and 434) were not measured. The $a_{\mathrm{cdom}, 330} / a_{\mathrm{t}, 330}$ ratios for Sta. S0 and 3 were estimated from the best fit of the $a_{\mathrm{cdom}, 330} / a_{\mathrm{t}, 330}$ ratio to salinity covering data with salinity $\leq 23.5\left(Y=0.025 X+0.42, R^{2}=0.922, n=10\right)$. The $a_{\mathrm{cdom}, 330} / a_{\mathrm{t}, 330}$ ratio for Sta. 434 was assumed equal to that for Sta. 391 based on their similar salinities (see Table 1). Absorption data for Baffin Bay (Sta. 126, 140, and 303) were obtained from Bélanger et al. (2008). Station 1526 refers to surface water $(5 \mathrm{~m})$ only. Keys for the "Region" column are the same as in Table 1.

\begin{tabular}{|c|c|c|c|c|c|c|c|c|c|}
\hline \multirow[t]{2}{*}{ Region } & \multirow[t]{2}{*}{ Station } & \multirow{2}{*}{$\begin{array}{r}a_{\text {cdom }, 330} \\
\left(\mathrm{~m}^{-1}\right)\end{array}$} & \multirow{2}{*}{$\begin{array}{r}a_{\mathrm{cdom}, 330} / \\
a_{\mathrm{t}, 330}\end{array}$} & \multirow{2}{*}{$\begin{array}{l}\text { UMLD } \\
\text { (m) }\end{array}$} & \multirow{2}{*}{$\begin{array}{r}\mathrm{Z}_{1 \%, 330} \\
(\mathrm{~m})\end{array}$} & $Q_{\mathrm{d}, 0-}$ & PAR & UV & \multirow{2}{*}{$\begin{array}{r}k_{\mathrm{dms}} \\
\left(\mathrm{d}^{-1}\right)\end{array}$} \\
\hline & & & & & & \multicolumn{3}{|c|}{ (mol photons $\mathrm{m}^{-2} \mathrm{~d}^{-1}$ ) } & \\
\hline \multirow[t]{7}{*}{ MRE-E } & So & 9.76 & 0.42 & 1.0 & 0.2 & 18.7 & 50.77 & 4.14 & 0.039 \\
\hline & 3 & 6.87 & 0.7 & 3.0 & 0.5 & 14.3 & 38.8 & 3.17 & 0.043 \\
\hline & 391 & 0.58 & 0.87 & 4.0 & 6.9 & 7.03 & 18.36 & 1.61 & 0.11 \\
\hline & 394 & 3.50 & 0.92 & 4.0 & 1.2 & 5.47 & 13.97 & 1.28 & 0.026 \\
\hline & 396 & 4.97 & 0.90 & 4.0 & 0.8 & 5.47 & 13.97 & 1.28 & 0.026 \\
\hline & 398 & 5.44 & 0.83 & 3.1 & 0.7 & 5.47 & 13.97 & 1.28 & 0.032 \\
\hline & 434 & 1.29 & 0.87 & 4.5 & 3.1 & 19.4 & 52.80 & 4.25 & 0.059 \\
\hline \multirow[t]{5}{*}{ MER-W } & 691 & 1.77 & 0.95 & 4.0 & 2.5 & 10.6 & 28.7 & 2.37 & 0.045 \\
\hline & 693 & 5.26 & 0.78 & 4.5 & 0.7 & 10.6 & 28.7 & 2.37 & 0.048 \\
\hline & 694 & 7.42 & 0.77 & 4.5 & 0.5 & 10.6 & 28.7 & 2.37 & 0.012 \\
\hline & 695 & 8.39 & 0.60 & 4.0 & 0.3 & 10.6 & 28.7 & 2.37 & 0.030 \\
\hline & 697 & 9.32 & 0.35 & 1.7 & 0.2 & 10.6 & 28.7 & 2.37 & 0.014 \\
\hline \multirow[t]{2}{*}{ MS } & 170 & 0.93 & 0.66 & 11.5 & 3.3 & 10.7 & 28.45 & 2.42 & 0.010 \\
\hline & 670 & 1.32 & 0.96 & 10.5 & 3.4 & 7.60 & 19.64 & 1.77 & 0.042 \\
\hline \multirow[t]{3}{*}{$\mathrm{CB}$} & 320 & 0.29 & 0.93 & 12.5 & 14.7 & 11.2 & 30.53 & 2.42 & 0.015 \\
\hline & 640 & 1.18 & 0.96 & 9.5 & 3.7 & 8.07 & 21.12 & 1.86 & 0.030 \\
\hline & 1526 & 0.57 & 0.93 & 19.0 & 7.5 & 19.3 & 52.77 & 4.21 & 0.010 \\
\hline \multirow[t]{3}{*}{ BB } & 126 & 0.28 & 0.92 & 12.5 & 15.1 & 2.00 & 5.02 & 0.44 & 0.028 \\
\hline & 140 & 0.29 & 0.92 & 17.5 & 14.6 & 3.53 & 9.22 & 0.78 & 0.030 \\
\hline & 303 & 0.40 & 0.92 & 11.5 & 10.5 & 3.56 & 9.11 & 0.80 & 0.023 \\
\hline
\end{tabular}

Arctic (Leck and Persson, 1996). Most of our photochemical DMS turnover times (i.e., $1 / k_{\mathrm{dms}}$, range: 9-100 d; mean: $29 \mathrm{~d}$ ) are longer than even the slowest bacterial DMS uptake so far observed in the Arctic. Hence, photolysis of DMS is generally not expected to be the dominant loss term of this compound in Arctic seawater. There are no published bacterial DMS consumption data for the areas surveyed by the present study. However, the DMS turnover times with respect to microbial DMS production in these areas are known to range from 1 to $19 \mathrm{~d}$ and average $6 \mathrm{~d}$ (Luce et al., 2011), which are equivalent to the DMS gross loss turnover times (Kiene and Linn, 2000). Photooxidation thus on average accounts for $21 \%$ of the DMS gross loss term. Yet, the photochemical turnover times are similar in magnitude to the air-sea ventilation turnover times (Beaufort Sea: 2.2-57d; Baffin Bay: 15-162d); the latter were estimated using an UMLD of $\sim 15 \mathrm{~m}$ (Table 3, excluding the two estuarine transects) and mixed-layer DMS concentrations (Beaufort Sea: $0.38 \mathrm{nmol} \mathrm{L}^{-1}$; Baffin Bay: $1.3 \mathrm{nmol} \mathrm{L}^{-1}$ ) and air-sea exchange fluxes (Beaufort Sea: 0.1-2.6 $\mu \mathrm{mol} \mathrm{m}{ }^{-2} \mathrm{~d}^{-1}$; Baffin Bay: $\left.0.2-1.3 \mu \mathrm{mol} \mathrm{m}^{-2} \mathrm{~d}^{-1}\right)$ collected from the same areas and seasons (Luce et al., 2011; Motard-Côté et al., 2012; Rempillo et al., 2011).

Lastly, all samples in the present study were taken in the summer and fall seasons when surface waters were depleted in nitrate except those within the Mackenzie River plume (Table 1). According to Tremblay et al. (2008), surface water nitrate concentrations in the coastal and offshore SE Beaufort Sea reach a maximum of $\sim 4 \mu \mathrm{mol} \mathrm{L}^{-1}$ in late April and early May when sea ice usually starts to break up. This level of nitrate would increase the DMS AQY by 50\%, translating to a $50 \%$ reduction in the photochemical DMS turnover time. Under otherwise similar conditions, the photochemical DMS turnover is thus expected to be faster in spring, i.e., on the order of $\sim 14 \mathrm{~d}$, which is comparable to the lower end of the biological DMS turnover estimates for the Arctic Ocean.

\section{Summary}

Salinity was identified as a good indicator of the DMS AQYs determined from estuarine, shelf, and open ocean waters in the Canadian Arctic. Surface water DMS AQY in the UV 
Table 4. Photochemical DMS turnover rate constants in the surface layer (SL) from this study and the literature. Mackenzie Shelf includes MER-E and MER-W as defined in Table 1.

\begin{tabular}{llrrl}
\hline Area & Season & $\begin{array}{r}k_{\mathrm{dms}} \\
\left(\mathrm{d}^{-1}\right)\end{array}$ & $\begin{array}{r}\text { SL depth } \\
(\mathrm{m})\end{array}$ & Reference \\
\hline Mackenzie Shelf & Jun-Aug & $0.01-0.11$ & $1-4.5^{\mathrm{a}}$ & This study \\
Canada Basin & Jul-Aug & $0.010-0.030$ & $9.5-19^{\mathrm{a}}$ & This study \\
Baffin Bay & Sep & $0.023-0.030$ & $11.5-17.5^{\mathrm{a}}$ & This study \\
Equatorial Pacific & Feb-Mar & $0.1-0.3$ & $20^{\mathrm{b}}$ & Kieber et al. (1996) \\
Equatorial Pacific & Feb-Mar & $0.05-0.15$ & $60^{\mathrm{a}}$ & Kieber et al. (1996) \\
North Adriatic Sea & Aug-Sep & 0.4 & $10^{\mathrm{b}}$ & Brugger et al. (1998) \\
North Adriatic Sea & Aug-Sep & 0.14 & $20^{\mathrm{b}}$ & Brugger et al. (1998) \\
North Atlantic & Jun & $0.04-2.5$ & $2-39^{\mathrm{a}}$ & Simó and Pedrós-Alió (1999) \\
North Sea & Jun & $0.10-0.37$ & $20^{\mathrm{b}}$ & Hatton (2002) \\
Sargasso Sea & Jul & $0.05-0.22$ & $15-20^{\mathrm{a}}$ & Toole et al. (2003) \\
Ross Sea & Nov & $0.5-0.71$ & $100^{\mathrm{a}}$ & Toole et al. (2004) \\
Bering Sea & Aug & $0.02-0.11$ & $20-40^{\mathrm{a}}$ & Deal et al. (2005) \\
Northeast Pacific & Jul & $0.03-0.25$ & $10-30^{\mathrm{a}}$ & Bouillon et al. (2006) \\
Sargasso Sea & Jul-Aug & $0.48-0.6$ & $20^{\mathrm{b}}$ & Gabric et al. (2008) \\
Ross Sea & Jan & $0.037-0.17$ & $88^{\mathrm{b}}$ & del Valle et al. (2009) \\
Greenland Sea & Jul & $0.23-1.05$ & $1.5-11^{\mathrm{a}}$ & Galí and Simó (2010) \\
\hline
\end{tabular}

${ }^{a}$ SL depth matches the upper mixed-layer depth. ${ }^{b}$ SL depth does not match the upper mixed-layer depth.

domain increased linearly with the spectral slope coefficient of CDOM, suggesting that marine CDOM was more efficient than terrestrial CDOM at photosensitizing the decomposition of DMS or that there were higher concentrations of scavengers of DMS-oxidizing radical intermediates. This approach of linking DMS AQYs to CDOM quality/origin, if confirmed elsewhere, may lead to broad implications for studying photochemical cycling of DMS and perhaps other compounds as well. High DMS AQYs observed in nitraterich deep water samples were attributable to enhanced DMS degradation by radicals produced from nitrate photolysis. UV-A was the dominant spectral range of solar radiation responsible for DMS photooxidation both at the surface and on a depth-integrated basis. Coupled optical-photochemical modeling indicated that photochemical DMS turnover in the water column was controlled by diverse variables, among which the mixed-layer depth, AQY, solar irradiance, and the contribution of CDOM to the total underwater light absorption were the most important. Modeled photochemical DMS turnover times ranged from 9 to $100 \mathrm{~d}$ (mean: $29 \mathrm{~d}$ ) and were similar to the atmospheric ventilation turnover times. It is suggested that the photochemical DMS turnover in spring could be twice as fast because of higher nitrate concentrations in surface water at the start of ice break up.
Acknowledgements. We thank S. Michaud for technical assistance and appreciate the cooperation of the chief scientists, captains, and crews of the Arctic SOLAS, CFL, and MALINA cruises. Reviewers' and editor's comments improved the manuscript. This study was supported by grants from the IPY federal program office and the Natural Sciences and Engineering Research Council of Canada (NSERC). A. Taalba was supported by HX's SOLAS, CFL, NSERC Discovery funds and by internal funds of the Institut des sciences de la mer de Rimouski (ISMER). The Arctic SOLAS, CFL and MALINA programs are under the overall directions of M. Levasseur, D. Barber, and M. Babin, respectively. This is a contribution to the research programs of Arctic SOLAS, CFL, MALINA, ISMER, and Québec-Océan.

Edited by: W. Miller

\section{References}

Amon, R. M. W. and Meon, B.: The biogeochemistry of dissolved organic matter and nutrients in two large Arctic estuaries and potential implications for our understanding of the Arctic Ocean system, Mar. Chem., 92, 311-330, 2004.

Andreae, M. O. and Crutzen, P. J.: Atmospheric aerosols: Biogeochemical sources and role in atmospheric chemistry, Science, 276, 1052-1058, 1997.

Babin, M., Stramski, D., Ferrari, G. M., Claustre, H., Bricaud, A., Obolensky, G., and Hoepffner, N.: Variations in the light absorption coefficients of phytoplankton, nonalgal particles, and dissolved organic matter in coastal waters around Europe, J. Geophys. Res., 108, 3211, doi:10.1029/2001JC000882, 2003.

Bates, T. S., Lamb, B. K., Guenther, A., Dignon, J., and Stoiber, R. E.: Sulfur emissions to the atmosphere from natural sources, J. Atmos. Chem., 14, 315-337, 1992. 
Bélanger, S., Xie, H., Krotkov, N., Larouche, P., Vincent, W. F., and Babin, M.: Photomineralization of terrigenous dissolved organic matter in Arctic coastal waters from 1979 to 2003: Interannual variability and implications of climate change, Global Biogeochem. Cy., 20, GB4005, doi:10.1029/2006GB002708, 2006.

Bélanger, S., Babin, M., and Larouche, P.: An empirical ocean color algorithm for estimating the contribution of chromophoric dissolved organic matter to total light absorption in optically complex waters, J. Geophys. Res., 113, C04027, doi:10.1029/2007JC004436, 2008.

Benner, R. H.: Cycling of dissolved organic in the ocean, in: Aquatic humic substances: Ecology and biogeochemistry, edited by: Hessen, D. O. and Tranvik, L. J., Springer-Verlag, Berlin, Germany, 317-331, 1998.

Bouillon, R.-C. and Miller, W. L.: Determination of apparent quantum yield spectra of DMS photo-degradation in an in situ ironinduced Northeast Pacific Ocean bloom, Geophys. Res. Lett., 31, L06310, doi:10.1029/2004GL019536, 2004.

Bouillon, R.-C. and Miller, W. L.: Photodegradation of dimethyl sulfide (DMS) in natural waters: Laboratory assessment of the nitrate-photolysis-induced DMS oxidation, Environ. Sci. Technol., 39, 9471-9477, 2005.

Bouillon, R.-C., Lee, P. A., de Mora, S. J., Levasseur, M., and Lovejoy, C.: Vernal distribution of dimethylsulphide, dimethylsulphoniopropionate, and dimethylsulphoxide in the North Water in 1998, Deep-Sea Res. Pt. II, 49, 5171-5189, 2002.

Bouillon, R.-C., Miller, W. L., Levasseur, M., Scarratt, M., Merzouk, A., Michaud, S., and Ziolkowski, L.: The effect of mesoscale iron enrichment on the marine photochemistry of dimethylsulfide in the NE subarctic Pacific, Deep-Sea Res. Pt. II, 53, 2384-2397, 2006.

Brimblecombe, P. and Shooter, D.: Photo-oxidation of dimethylsulphide in aqueous solution, Mar. Chem., 19, 343-353, 1986.

Brugger, A., Slezak, D., Obernosterer, I., and Herndl, G. J.: Photolysis of dimethylsulfide in the northern Adriatic Sea: Dependence on substrate concentration, irradiance and DOC concentration, Mar. Chem., 59, 321-331, 1998.

Buiteveld, H., Hakvoort, J. M. H., and Donze, M.: The optical properties of pure water, in: SPIE proceeding on ocean optics XII. The Society of Photo-Optical Instrumentation Engineers, edited by: Jaffe, J. S., 174-183, 1994.

Chang, R. Y.-W., Sjostedt, S. J., Pierce, J. R., Papakyriakou, T. N., Scarratt, M. G., Michaud, S., Levasseur, M., Leaitch, W. R., and Abbatt, J. P. D.: Relating atmospheric and oceanic DMS levels to particle nucleation events in the Canadian Arctic, J. Geophys. Res., 116, D00S03, doi:10.1029/2011JD015926, 2011.

Charlson, R. J., Lovelock, J. E., Andreae, M. O., and Warren, S. G.: Oceanic phytoplankton, atmospheric sulphur, cloud albedo and climate, Nature, 326, 655-661, 1987.

Comiso, J. C.: Abrupt decline in the Arctic winter sea ice cover, Geophys. Res. Lett., 33, L18504, doi:10.1029/2006GL027341, 2006.

Deal, C., Kieber, D., Toole, D., Stamnes, K., Jiang, S., and Uzuka, N.: Dimethylsulfide photolysis rates and apparent quantum yields in Bering Sea seawater, Cont. Shelf Res., 25, 18251835, 2005.

Del Valle, D. A., Kieber, D. J., Toole, D. A., Brinkley, J., and Kiene, R. P.:, Biological consumption of dimethylsulfide (DMS) and its importance in DMS dynamics in the Ross Sea, Antarctica, Limnol. Oceanogr., 54, 785-798, 2009.

Fichot, C. G. and Benner, R.: The spectral slope coefficient of chromophoric dissolved organic matter $\left(S_{275-295}\right)$ as a tracer of terrigenous dissolved organic carbon in river-influenced ocean margins, Limnol. Oceanogr., 57, 1453-1466, 2012.

Fichot, C. G., Kaiser, K., Hooker, S. B., Amon, R. M. W., Babin, M., Bélanger, S., Walker, S. A., and Benner, R.: Pan-Arctic distributions of continental runoff in the Arctic Ocean, Sci. Rep., 3, 1053, doi:10.1038/srep01053, 2013.

Gabric, A. J., Qu, B., Matrai, P., and Hirst, A. C.: The simulated response of dimethylsulfide production in the Arctic Ocean to global warming, Tellus B, 57, 391-403, doi:10.1111/j.16000889.2005.00163.x, 2005.

Galí, M. and Simó, R.: Occurrence and cycling of dimethylated sulfur compounds in the Arctic during summer receding of the ice edge, Mar. Chem., 122, 105-117, 2010.

Grasshoff, K., Ehrhardt, M., Kremling, K., and Anderson, L. G.: Methods of Seawater Analysis. Wiley-VCH, Weinheim, New York, 1999.

Gueymard, C. A.: Parameterized transmittance model for direct beam and circumsolar spectral irradiance, Sol. Energy, 71, 325346, 2001.

Helms, J. R., Stubbins, A., Ritchie, J. D., Minor,E. C., Kieber, D. J., and Mopper, K.: Absorption spectral slopes and slope ratios as indicators of molecular weight, source, and photobleaching of chromophoric dissolved organic matter, Limnol. Oceanogr., 53, 955-969, 2008.

Johannessen, S. C. and Miller, W. L.: Quantum yield for the photochemical production of dissolved inorganic carbon in seawater, Mar. Chem., 76, 271-283, 2001.

Kettle, A. J., Andreae, M. O., Amouroux, D., Andreae, T. W., Bates, T. S., Berresheim, H., Bingemer, H., Boniforti, R., Curran, M. A J., DiTullio, G. R., Helas, G., Jones, G. B., Keller, M. D., Kiene, R. P., Leck, C., Levasseur, M., Malin, G., Maspero, M., Matrai, P., McTaggart, A. R., Mihalopoulos, N., Nguyen, B. C., Novo, A., Putaud, J. P., Rapsomanikis, S., Roberts, G., Schebeske, G., Sharma, S., Simo, R., Staubes, R., Turner, S., and Uher, G.: A global database of sea surface dimethylsulfide (DMS) measurements and a procedure to predict sea surface DMS as a function of latitude, longitude, and month, Global Biogeochem. Cy., 13, 399-444, 1999.

Kieber, D. J., Jiao, J., Kiene, R. P., and Bates, T. S.: Impact of dimethylsulfide photochemistry on methyl sulfur cycling in the equatorial Pacific Ocean, J. Geophys. Res., 101, 3715-3722, 1996.

Kiene, R. P. and Bates, T. S.: Biological removal of dimethyl sulphide from sea water, Nature, 345, 702-705, 1990.

Kiene, R. P. and Linn, L. J.: The fate of dissolved dimethylsulfoniopropionate (DMSP) in seawater: Tracer studies using ${ }^{35} \mathrm{~S}$-DMSP, Geochim. Cosmochim. Ac., 64, 2797-2810, 2000.

Kiene, R. P., Linn, L. J., and Bruton, J. A.: New and important roles for DMSP in marine microbial communities, J. Sea Res., 43, 209-224, 2000.

Kulmala, M., Kontkanen, J., Junninen, H., Lehtipalo, K., Manninen, H. E., Nieminen, T., Petaja, T., Sipila, M., Schobesberger, S., Rantala, P., Franchin, A., Jokinen, T., Jarvinen, E., Aijala, M., Kangasluoma, J., Hakala, J., Aalto, P. P., Paasonen, P., Mikkila, J., Vanhanen, J., Aalto, J., Hakola, H., Makkonen, U., Ruuska- 
nen, T., Mauldin, R. L., Duplissy, J., Vehkamaki, H., Back, J., Kortelainen, A., Riipinen, I., Kurten, T., Johnston, M. V., Smith, J. N., Ehn, M., Mentel, T. F., Lehtinen, K. E. J., Laaksonen, A., Kerminen, V.-M., and Worsnop, D. R.: Direct Observations of Atmospheric Aerosol Nucleation, Science, 339, 943946, doi:10.1126/science.1227385, 2013.

Lana, A., Bell, T. G., Simó, R., Vallina, S. M., Ballabrera-Poy, J., Kettle, A. J., Dachs, J., Bopp, L., Saltzman, E. S., Stefels, J., Johnson, J. E., and Liss, P. S.: An updated climatology of surface dimethlysulfide concentrations and emission fluxes in the global ocean, Global Biogeochem. Cy., 25, GB1004, doi:10.1029/2010GB003850, 2011.

Lana, A., Simó, R., Vallina, S. M., and Dachs, J.: Potential for a biogenic influence on cloud microphysics over the ocean: a correlation study with satellite-derived data, Atmos. Chem. Phys., 12, 7977-7993, doi:10.5194/acp-12-7977-2012, 2012.

Leck, C. and Persson, C.: The central Arctic Ocean as a source of dimethyl sulfide - Seasonal variability in relation to biological activity, Tellus, B, 48, 156-177, 1996.

Liss, P. S., Hatton, A. D., Malin, G., Nightingale, P. D., and Turner, S. M.: Marine sulphur emissions, Philos. T. R. Soc. Lon. B, 352, 159-169, 1997.

Luce, M., Levasseur, M., Scarratt, M. G., Michaud, S., Royer, S.-J., Kiene, R., Lovejoy, C., Gosselin, M., Poulin, M., Gratton, Y., and Lizotte, M.: Distribution and microbial metabolism of dimethylsulfoniopropionate and dimethylsulfide during the 2007 Arctic ice minimum, J. Geophys. Res., 116, C00G06, doi:10.1029/2010JC006914, 2011.

Mack, J. and Bolton, J. R.: Photochemistry of nitrite and nitrate in aqueous solution: a review, J. Photoch. Photobio. A, 128, 1-13, 1999.

Matrai, P. A. and Vernet, M.: Dynamics of the vernal bloom in the marginal ice-zone of the Barents Sea: Dimethyl sulfide and dimethylsulfoniopropionate budgets, J. Geophys. Res., 102, 22965-22979, 1997.

Matsuoka, A., Bricaud, A., Benner, R., Para, J., Sempéré, R., Prieur, L., Bélanger, S., and Babin, M.: Tracing the transport of colored dissolved organic matter in water masses of the Southern Beaufort Sea: relationship with hydrographic characteristics, Biogeosciences, 9, 925-940, doi:10.5194/bg-9-925-2012, 2012.

Melling, H., Gratton, Y., and Ingram, G.: Ocean circulation within the North Water polynya of Baffin Bay, Atmos.-Ocean, 39, 301325, doi:10.1080/07055900.2001.9649683, 2001.

Miller, W., King, D. W., Lin, J., and Kester, D. R.: Photochemical redox cycling of iron in coastal seawater, Mar. Chem., 50, 63-67, 1995.

Motard-Côté, J., Levasseur, M., Scarratt, M. G., Michaud, S., Gratton, Y., Rivkin, R. B., Keats, K., Gosselin, M., Tremblay, J.-É., Kiene, R. P., and Lovejoy, C.: Distribution and metabolism of dimethylsulfoniopropionate (DMSP) and phylogenetic affiliation of DMSP-assimilating bacteria in northern Baffin Bay/Lancaster Sound, J. Geophys. Res., 117, C00G11, doi:10.1029/2011JC007330, 2012.

Pope, R. M. and Fry, E. S.: Absorption spectrum (380-700 nm) of pure water. 2. Integrating cavity measurements, Appl. Optics, 36, 8710-8723, 1997.

Quinn, P. K. and Bates, T. S.: The case against climate regulation via oceanic phytoplankton sulphur emissions, Nature, 480, 51$56,2011$.
Rabe, B., Karcher, M., Schauer, U., Toole, J. M., Krishfield, R. A., Pisarev, S., Kauker, F., Gerdes, R., and Kikuchi, T.: An assessment of Arctic Ocean freshwater content changes from the 1990s to the 2006-2008 period, Deep-Sea Res. Pt. I, 58, 173-185, 2011.

Rempillo, O., Seguin, A. M., Norman, A.-L., Scarratt, M., Michaud, S., Chang, R., Sjostedt, S., Abbatt, J., Else, B., Papakyriakou, T., Sharma, S., Grasby, S., and Levasseur, M.: Dimethyl sulfide air-sea fluxes and biogenic sulfur as a source of new aerosols in the Arctic fall, J. Geophys. Res., 116, D00S04, doi:10.1029/2011JD016336, 2011.

Retamal, L., Bonilla, S., and Vincent, W. F.: Optical gradients and phytoplankton production in the Mackenzie River and the coastal Beaufort Sea, Polar Biol., 31, 363-379, 2008.

Rex, M., Salawitch, R. J., von der Gathen, P., Harris, N. R. P., Chipperfield, M. P., and Naujokat, B.: Arctic ozone loss and climate change, Geophys. Res. Lett., 31, L04116, doi:10.1029/2003GL018844, 2004.

Ricchiazzi, P., Yang, S., and Gautier, C.: A Practical Tool for PlaneParallel Radiative Transfer in the Earth's Atmosphere, available at http://arm.mrcsb.com/sbdart/html/sbdart-intro.html, 1998.

Rundel, R. D.: Action spectra and estimation of biologically effective UV radiation, Physiol. Plantarium, 58, 360-366, 1983.

Scarratt, M., Cantin, G., Levasseur, M., and Michaud, S.: Particle size-fractionated kinetics of DMS production: where does DMSP cleavage occur at the microscale?, J. Sea Res., 43, 245252, 2000.

Sharma, S., Barrie, L. A., Plummer, D., McConnell, J. C., Brickell, P. C., Levasseur, M., Gosselin, M., and Bates, T. S.: Flux estimation of oceanic dimethyl sulfide around North America, J. Geophys. Res., 104, 21327-21342, 1999.

Simó, R.: From cells to globe: approaching the dynamics of DMS(P) in the ocean at multiple scales, Can. J. Fish. Aquat. Sci., 61, 673-684, 2004.

Simó, R. and Pedrós-Alió, C.: Short-term variability in the open ocean cycle of dimethylsulfide, Global Biogeochem. Cy., 13, 1173-1181, 1999.

Song, G., Xie, H., Bélanger, S., Leymarie, E., and Babin, M.: Spectrally resolved efficiencies of carbon monoxide $(\mathrm{CO})$ photoproduction in the western Canadian Arctic: particles versus solutes, Biogeosciences, 10, 3731-3748, doi:10.5194/bg-10-3731-2013, 2013.

Stedmon, C. A., Amon, R. M. W., Rinehart, A. J., and Walker, S. A.: The supply and characteristics of colored dissolved organic matter (CDOM) in the Arctic Ocean: Pan Arctic trends and differences, Mar. Chem., 124, 108-118, 2011.

Stefels, J., Steinke, M., Turner, S., Malin, G., and Belviso, S.: Environmental constraints on the production and removal of the climatically active gas dimethylsulphide (DMS) and implications for ecosystem modelling, Biogeochemistry, 83, 245-275, 2007.

Toole, D. A., Kieber, D. J., Kiene, R. P., Siegel, D. A., and Nelson, N. B.: Photolysis and the dimethylsulfide (DMS) summer paradox in the Sargasso Sea, Limnol. Oceangr., 48, 1088-1100, 2003.

Toole, D. A., Kieber, D. J., Kiene, R. P., White, E. M., Bisgrove, J., del Valle, D. A., and Slezak, D.: High dimethyl sulfide photolysis rates in nitrate-rich Antarctic waters, Geophys. Res. Lett., 31, L11307 doi:10.1029/2004GL019863, 2004.

Tremblay, J.-É, Simpson, K., Martin, J., Miller, L., Gratton, Y., Barber, D., and Price, N. M.: Vertical stability and the an- 
nual dynamics of nutrients and chlorophyll fluorescence in the coastal, southeast Beaufort Sea, J. Geophys. Res., 113, C07S90, doi:10.1029/2007JC004547, 2008.

Westerhoff, D., Mezyk, S. P., Cooper, W. J., and Minakata, D.: Electron pulse radiolysis determination of hydroxyl radical rate constants with Suwannee River fulvic acid and other dissolved organic matter isolates, Environ. Sci. Technol., 41, 4640-4646, 2007.

Xie, H., Moore, R. M., and Miller, W. L.: Photochemical production of carbon disulphide in seawater, J. Geophys. Res., 103, 56355644, 1998.

Xie, H., Bélanger, S., Demers, S., Vincent, W. F., and Papakytiakou, T. N.: Photobiogeochemical cycling of carbon monoxide in the southeastern Beaufort Sea in spring and autumn, Limnol. Oceanogr., 54, 234-249, 2009.

Xie, H., Bélanger, S., Song, G., Benner, R., Taalba, A., Blais, M., Tremblay, J.-É., and Babin, M.: Photoproduction of ammonium in the southeastern Beaufort Sea and its biogeochemical implications, Biogeosciences, 9, 3047-3061, doi:10.5194/bg-9-30472012, 2012.
Yang, G.-P., Li., C., Qi, J., Hu, L., and Hou, H.: Photochemical oxidation of dimethylsulfide in seawater, Acta Oceanol. Sin., 26, 34-42, 2007.

Yang, G.-P., Zhang, H.-H., Zhou, L.-M., and Yang, J.: Temporal and spatial variations of dimethylsulfide (DMS) and dimethylsulfoniopropionate (DMSP) in the East China Sea and the Yellow Sea, Cont. Shelf Res., 31, 1325-1335, 2011.

Yoch, D. C.: Dimethylsulfoniopropionate: Its sources, role in the marine food web, and biological degradation to dimethylsulfide, Appl. Environ. Microb., 68, 5804-5815, 2002.

Zepp, R. G.: Solar UVR and aquatic carbon, nitrogen, sulfur and metals cycles, in: UV effects in aquatic organisms and ecosystems, edited by: Helbling, E. W. and Zagarese, H., The Royal Society of Chemistry, London, 137-184, 2003.

Zhang, Y., Xie, H., and Chen, G.: Factors Affecting the Efficiency of Carbon Monoxide Photoproduction in the St. Lawrence Estuarine System (Canada), Environ. Sci. Technol., 40, 7771-7777, doi:10.1021/es0615268, 2006. 